Jurnal Ilmiah KONTEKSTUAL

Volume 3, No. 01, Agustus 2021, p. 33-41

\title{
APLIKASI EDUKEY SEBAGAI SARANA BIMBINGAN BELAJAR DARING UNTUK SISWA BERKEBUTUHAN KHUSUS
}

\section{EDUKEY APPLICATION: ONLINE TUTORING TOOL FOR STUDENTS WITH SPECIAL NEEDS}

\author{
Argorby Simanullang*1, Tabitha Grace Larasati ${ }^{2}$, Wiputra Cendana ${ }^{3}$ \\ ${ }^{1,2}$ Program Studi Pendidikan Biologi, Fakultas Ilmu Pendidikan, Universitas Pelita Harapan, Indonesia \\ ${ }^{3}$ Program Studi Pendidikan Guru Sekolah Dasar, Fakultas Ilmu Pendidikan, Universitas Pelita Harapan, \\ Indonesia \\ e-mail:*1as80021@student.uph.edu, 20t180009@student.uph.ed, 3wiputra.cendana@uph.edu
}

\begin{abstract}
ABSTRAK
Pembelajaran jarak jauh yang dilaksanakan di masa pandemi COVID-19 ini berdampak besar kepada pemahaman siswa di dalam kegiatan belajar mengajar, khususnya untuk anak-anak berkebutuhan khusus yang bersekolah di SLB maupun sekolah inklusif. Tujuan penelitian ini adalah untuk mengkaji penggunaan aplikasi EDUKEY sebagai sarana bimbingan belajar daring untuk anak berkebutuhan khusus. Metode yang dipakai adalah deskriptifkualitatifyang berfokus pada respon pengguna aplikasi dan diolah lagi di dalam metode WSLC atau The Work System Life Cycle Model. Hasil penelitian menunjukkan aplikasi EDUKEY membantu peserta didik melakukan kegiatan belajar mengajar secara daring karena merasa dimudahkan dengan fitur-fitur yang ada. Selain itu, umpan balik yang diberikan pengguna terhadap aplikasi EDUKEY kebanyakan positif dan sesuai dengan tujuan peneliti membuat aplikasi ini. Saran yang dapat diberikan adalah sebaiknya aplikasi EDUKEY lebih dikembangkan lagi untuk melayani pengguna dengan keterbatasan lainnya, tidak hanya slow learner, tunalaras, dan kesulitan belajar. Maka dari itu, aplikasi EDUKEY sangat penting untuk dikembangkan agar semakin banyak orang merasakan manfaatnya.
\end{abstract}

Kata kunci: aplikasi, edukey, pengguna, respon, siswa berkebutuhan khusus

\begin{abstract}
Online learning, which was carried out during the COVID-19 pandemic, has a major impact on students' understanding in teaching and learning activities, not only children who attend regular schools, especially for children with special needs who attend SLB and inclusive schools. The purpose of this research is to examine the use of the EDUKEY application as a means of online tutoring for children with special needs. The method used is descriptive qualitative which focuses on the response of application users and processed again in the WSLC method or The Work System Life Cycle Model. The results obtained are EDUKEY application help students carry out online teaching and learning activities because they feel facilitated by the features available. In addition, the feedback given by users to the EDUKEY application is mostly positive and is in accordance with the researcher's goal of making this application. The suggestion that can be given is that the EDUKEY application should be further developed to serve users with other limitations, not only slow learners, hearing impaired, and learning difficulties. Therefore, the EDUKEY application is very important to be developed so that more people feel the benefits.
\end{abstract}

Keywords: application, children with special needs, edukey, response, user 


\section{PENDAHULUAN}

Pandemi COVID-19 yang harus dilalui pada saat ini berdampak pada banyak bidang, tidak terkecuali bidang pendidikan. Institusi pembelajaran formal maupun nonformal banyak yang menerapkan sistem PJJ (Pembelajaran Jarak Jauh) untuk tetap menjalankan kegiatan belajar mengajar. PJJ memungkinkan pengajar dan siswa dapat melakukan pembelajaran kapanpun dan dimanapun [1]. Pembelajaran Jarak Jauh (PJJ) dapat dilaksanakan dengan tujuan peningkatan kualitas sarana prasarana pendidikan dan pemerataan akses pendidikan ke daerah-daerah [1]. Sistem PJJ berbasis online membawa dampak yang baik kepada pengajar dan siswa, baik siswa biasa maupun siswa yang memiliki kebutuhan khusus, seperti slow learner, tunalaras, dan kesulitan belajar [2].

Semua anak berhak mendapatkan pendidikan dengan optimal, termasuk anak-anak dengan kebutuhan khusus, terutama yang adalah slow learner dan tunalaras. Anak berkebutuhan khusus adalah anak yang memiliki pertumbuhan sikap dan karakter yang unik dan berbeda dengan anak pada umumnya. Anak berkebutuhan khusus menunjukkan perbedaan, baik kurang maupun lebih pada mental, emosi, ataupun fisik [2]. Anak berkebutuhan khusus juga berhak untuk mendapatkan pendidikan seperti anak biasa, tetapi dengan pelayanan khusus seperti dalam sekolah inklusi. Anak berkebutuhan khusus terbagi ke dalam bermacam-macam kategorinya sehingga cara mereka belajar pun berbeda-beda disesuaikan dengan kekuatan dan keterbatasan mereka. Tiga kategori yang akan dibahas lebih lanjut adalah kategori slow learner, tunalaras, dan yang memiliki kesulitan belajar.

Slow learner atau anak-anak yang lambat belajar tidak dapat dikenali secara fisik, tetapi tetap harus didukung dengan layanan inklusi khusus untuk membantunya belajar dan tidak tertinggal progres teman-teman seusianya serta beradaptasi dengan kehidupan bermasyarakat. Anak slow learner biasanya adalah orang yang pemalu, pendiam, kurang percaya diri, dan sulit menangkap materi sehingga perlu dilakukan layanan pendidikan khusus [3]. Tunalaras adalah sebutan bagi anak yang mengalami hambatan dalam perkembangan dan pengendalian emosi, sosial, dan lain-lain yang mengakibatkan ketidakmatangan emosi dan perilaku yang tidak sesuai [4]. Perilaku anak tunalaras ada yang berisiko tinggi, seperti hiperaktif, pembangkang, dan ada juga yang berisiko rendah, contohnya autisme. Kesulitan belajar adalah kondisi seseorang yang kemampuannya untuk berpikir, membaca, menghitung memiliki gangguan yang disebabkan oleh brain injury, disfungsi otak secara minimal, disleksia, dan lain-lain [2].

Sekolah adalah bangunan atau lembaga untuk belajar dan mengajar serta tempat menerima dan memberi pelajaran dan mampu menampung setiap orang yang datang dan ingin mendapatkan pendidikan dalam pendidikan formal [5]. Namun pada faktanya, tidak semua orang dapat merasakan bersekolah di pendidikan formal. Penyebabnya adalah karena adanya perbedaan perlakuan pengajaran bagi beberapa orang [6]. Salah satunya adalah yang terjadi pada anak berkebutuhan khusus. Jarang anak berkebutuhan khusus dapat merasakan pendidikan yang layak sesuai dengan karakteristik dan kebutuhannya.

Anak berkebutuhan khusus merupakan kategori anak yang membutuhkan perhatian, penanganan, dan layanan khusus di dalam praktik belajar dikarenakan mereka mengalami kondisi kendala atau hambatan belajar dan dapat diterima di pendidikan inklusif yang akan menjamin setiap anak berkebutuhan khusus untuk dapat diterima di sekolah umum serta memperoleh akses pelayanan pendidikan yang layak dan sesuai dengan kebutuhannya masing-masing dan bersama anak normal [7]. Berdasarkan pernyataan para ahli di atas, dapat disimpulkan bahwa sesungguhnya anak berkebutuhan khusus yang mengalami kondisi terhambat untuk belajar berkesempatan dapat merasakan berbagai akses pendidikan inklusif dan dapat menyesuaikan dengan kebutuhannya dalam menjalani pendidikan. Kenyataannya masih terdapat kekurangan atau kendala dalam penyelanggaraan pendidikan untuk anak berkebutuhan khusus, misalnya dari tenaga pengajar dan sarana prasarana yang belum memadai. Pembelajaran jarak jauh yang sedang berlangsung juga menambah daftar kendala dalam proses belajar mengajar pada anak berkebutuhan khusus dalam sekolahnya masing-masing mengingat kondisi siswa dan guru masing-masing. 
EDUKEY atau Education Key adalah aplikasi online yang dapat diakses melalui website dan mobile app. Aplikasi ini adalah inovasi yang berupa bimbingan belajar online yang diperuntukkan untuk anak berkebutuhan khusus. Harapannya aplikasi ini dapat menjadi alat bantu belajar bagi anak berkebutuhan khusus sehingga mereka bisa terbantu untuk siap dalam menghadapi kondisi kelas yang sesungguhnya pada pembelajaran online dengan guru mereka di sekolah ataupun saat tatap muka nanti. Dalam aplikasi ini, anak berkebutuhan khusus akan dinamai sebagai tutee, dan para pengajar mereka akan disebut sebagai tutor. Para pengajar atau tutor akan berasal dari kalangan pendidik dan mahasiswa calon guru yang memenuhi persyaratan atau kualifikasi standar aplikasi untuk dapat mengajar anak berkebutuhan khusus, sedangkan untuk tutee berasal dari peserta didik pada berbagai jenjang kelas.

Aplikasi EDUKEY dibuat untuk memudahkan proses pembelajaran anak-anak berkebutuhan khusus, terutama anak-anak slow learner, tunalaras, dan kesulitan belajar. Hal ini karena aplikasi tersebut akan memuat berbagai metode pembelajaran dan dapat disesuaikan dengan kepribadian siswa masing-masing. Pembelajaran dengan menggunakan aplikasi yang tepat akan mendapatkan hasil yang efektif [8]. Lebih lanjut, aplikasi EDUKEY juga memungkinkan pengguna untuk memilih tutor yang cocok dengan dirinya dan memfasilitasi pembelajaran secara optimal karena tidak hanya belajar menggunakan video, tetapi juga ada interaksi tutor dengan tutee seperti pembelajaran pada umumnya.

EDUKEY dibuat dengan tujuan untuk memfasilitasi pengajar dalam pembelajaran yang berbasis daring untuk mengajar anak-anak berkebutuhan khusus dengan optimal dan membantu anak-anak berkebutuhan khusus untuk belajar secara maksimal yang sesuai dengan kepribadiannya masing-masing. EDUKEY diharapkan dapat bermanfaat untuk meningkatkan efektivitas kegiatan belajar mengajar, terutama pada anak berkebutuhan khusus slow learner, tunalaras, dan kesulitan belajar sehingga mendapatkan pembelajaran yang holistis dan mudah dimengerti lewat cara belajar yang paling cocok dengan dirinya.

Pembelajaran bagi anak berkebutuhan khusus akan memadukan pembelajaran yang holistik yang dapat menyentuh dan membentuk tataran kognisi, afektif, dan psikomotor mereka. Proses belajar dan mengajar akan menggunakan media video pembelajaran (tersedia di aplikasi) dan interaksi dalam kelas online (tersedia di aplikasi) dan memungkinkan untuk melibatkan bantuan aplikasi lainnya seperti platform virtual online Zoom atau Microsoft. Pengajaran yang diberikan oleh tutor kepada anak berkebutuhan khusus akan disesuikan dengan tipe karakteristik tutee dan kebutuhannya masing-masing.

Fitur-fitur aplikasi yang ada di dalam aplikasi akan digunakan dan diakses oleh empat kelompok pengguna, yaitu: 1) Siswa sebagai tutee, 2) pengajar sebagai tutor, 3) orang tua, 4) dan sekolah. Fitur untuk siswa terdiri dari: a) akses pembelajaran berdasarkan penggolongan tingkatan kelas, b) memilih judul atau jenis pembelajaran berdasarkan jenjang pendidikan dan kurikulum yang digunakan, c) bebas memilih jenis pengajar atau tutor yang tersedia dalam aplikasi yang disesuaikan dengan karakteristik dan kebutuhannya, d) menonton video pembelajaran dari tutor, e) mengakses materi yang tersedia berbentuk teks atau dokumen, f) menentukan dan mengikuti jadwal interaksi pembelajaran virtual bersama tutor, g) mengerjakan variasi penugasan atau project, h) fitur pengenalan dan pengembangan bakat dan keterampilan tutee, f) fitur apresiasi atas pencapaian tutee, dan g) konsultasi online dengan tutor. Fitur untuk pengajar atau tutor tersedia berupa: a) lesson plan, b) tutor bimbel (khusus tutor), c) desain pembelajaran berupa variasi model, pendekatan, strategi, metode, teknis yang digunakan untuk mengjar anak berkebutuhan khusus, d) video panduan atau tutorial, e) peningkatan kualitas guru berupa seminar, workshop, atau pelatihan online, f) layanan reward tutor, g) layanan konsultasi online guru kepada para ahli. Fitur untuk orang tua tersedia berupa: a) monitoring anak, b) Akses pendidikan dan pengembangan pengetahuan, karakter, dan keterampilan anak berupa materi teks, video-video tutorial, pelatihan, dan seminar online, dan c) layanan konsultasi online dengan para ahli. Fitur untuk sekolah tersedia berupa a) monitoring siswa, b) akses kurikulum, dan c) pelatihan pengembangan kualitas guru dalam mendidik anak berkebutuhan khusus.

Tujuan dibuat aplikasi ini adalah menjadi wadah yang dapat memenuhi kebutuhan masyarakat dalam dunia pendidikan, membantu untuk menyelesaikan permasalahan yang terjadi 
dalam pendidikan, menjadi media belajar yang disesuaikan dengan karakteristik dan kebutuhan peserta didik, berpartisipasi aktif dalam peningkatan mutu kualitas pendidikan anak berkebutuhan khusus, menolong anak berkebutuhan khusus agar siap dalam menghadapi pembelajaran di dalam kelas sesungguhnya, menjaring dan membentuk tenaga pendidik yang berkualitas dan berkompetensi dalam mendidik anak berkebutuhan khusus, dan menjadi role model bagi pendidikan anak berkebutuhan khusus. Penelitian ini sangat penting dilakukan untuk mengkaji penggunaan aplikasi EDUKEY sebagai sarana bimbingan belajar daring untuk anak berkebutuhan khusus.

\section{METODE PENELITIAN}

Penelitian ini menggunakan metode deskriptif kualitatif. Deskriptif kualitatif adalah teknik merekam sejumlah besar aspek situasi sehingga dapat menggambarkan makna data yang telah dikumpulkan secara umum dan menyeluruh. Data-datanya dapat berupa naskah wawancara, dokumen, gambar, tetapi bukan angka [9]. Penelitian ini dilakukan berfokus pada respon beberapa pengguna aplikasi EDUKEY dan testimoni setelah menggunakan aplikasi EDUKEY untuk melakukan bimbingan belajar berbasis online. Instrumen yang dipakai adalah kolom umpan balik.

Pendapat dan respon dari para pengguna diolah lagi di dalam metode WSLC atau The Work System Life Cycle Model. WSLC meyakini bahwa perkembangan suatu sistem dapat dicapai dari beberapa pengulangan yang megombinasikan perubaha-perubahan kecil yang membuat sistem dapat beradaptasi dan selalu dieksperimenkan untuk berkembang [10]. Selain itu, model ini menyatakan pandangan dinamis tentang cara kerja suatu sistem dan kondisi perubahannya yang terjadi seiring bejalannya waktu [11].

Tahap pertama dalam WSLC adalah operation and maintenance yaitu tahap operasi dan pemeliharaan. Pada tahap ini, dilakukan pengamatan atau observasi terhadap keadaan target atau sasaran aplikasi ini, yaitu siswa berkebutuhan khusus, lingkungan keluarganya, sekolah inklusif, kebutuhan berkaitan dengan pembelajaran online di rumah, sampai kapabilitas siswa berkebutuhan khusus dalam mengakses dan menggunakan media pembelajaran online. Pada tahap ini juga, data yang didapatkan diolah untuk menghasilkan solusi bahwa diperlukan aplikasi yang menunjang pembelajaran siswa berkebutuhan khusus sehingga mereka mendapatkan akses pendidikan dengan mudah.

Tahap kedua adalah initiation atau inisiasi. Pada tahap ini, peneliti menentukan media apa yang dapat memenuhi kebutuhan siswa berkebutuhan khusus dengan tepat sasaran. Gagasan untuk membuat suatu aplikasi bimbingan belajar online bagi siswa berkebutuhan khusus didapatkan pada tahap ini. Bukan hanya medianya, tetapi detail-detail dari aplikasi yang dibuat juga dianalisis dan ditemukan pada tahap ini sehingga dapat melanjutkan ke tahap yang ketiga.

Tahap ketiga adalah tahap development atau pengembangan yang bertujuan untuk menghasilkan produk yang berupa aplikasi EDUKEY yang akan memfasilitasi bimbingan belajar secara online bagi siswa berkebutuhan khusus. Hasil dari tahap ini, yang berupa aplikasi, diujicobakan kepada siswa berkebutuhan khusus, keluarganya, dan juga pihak sekolah. Setelah diujicobakan dan mendapat umpan balik atau respon, maka peneliti mendapatkan aspek-aspek penyempurnaan yang diperlukan untuk mengembangkan aplikasi ini. Tahap yang terakhir adalah tahap implmentation yang artinya mengimplementasikan masukan-masukan dari pengguna untuk membangun aplikasi yang sesuai target dan kebutuhan penggunanya.

\section{HASIL DAN PEMBAHASAN}

\section{Hasil Penelitian}

Penelitian ini berhasil menemukan sebuah aplikasi bimbingan belajar online yang dinamakan EDUKEY untuk membantu belajar anak berkebutuhan khusus dalam konteks pembelajaran daring. Aplikasi EDUKEY dapat digunakan melalui website dan mobile phone oleh siswa atau anak berkebutuhan khusus, tutor, orang tua, dan sekolah. Berikut gambaran fitur-fitur aplikasi EDUKEY yang dapat diakses berdasarkan penggunanya: 
Jurnal Ilmiah KONTEKSTUAL, Volume. 3, No.01, Agustus 2021, pp. 33-41

Tabel 1. Fitur Aplikasi Bimbel Online EDUKEY

\begin{tabular}{|c|c|c|c|}
\hline \multicolumn{4}{|c|}{ Fitur-Fitur } \\
\hline Siswa/tutee & Pengajar/Tutor & Orang tua & Sekolah \\
\hline $\begin{array}{l}\text { Registrasi atau Login } \\
\text { akun }\end{array}$ & $\begin{array}{l}\text { Registrasi atau Login } \\
\text { akun }\end{array}$ & $\begin{array}{l}\text { Registrasi atau login } \\
\text { akun }\end{array}$ & $\begin{array}{l}\text { Registrasi atau login } \\
\text { akun }\end{array}$ \\
\hline Akses Mata Pelajaran & Lesson Plan & Monitoring anak & Monitoring siswa \\
\hline $\begin{array}{l}\text { Pilih Jenis } \\
\text { Pembelajaran SD, SMP, } \\
\text { dan SMA }\end{array}$ & Tutor Bimbel & $\begin{array}{l}\text { Akses Pendidikan dan } \\
\text { pengembangan } \\
\text { pengetahuan, karakter, }\end{array}$ & Akses kurikulum \\
\hline $\begin{array}{l}\text { Bebas Pilih Tutor yang } \\
\text { tersedia berdasarkan } \\
\text { jenis pembelajaran. }\end{array}$ & $\begin{array}{l}\text { Desain variasi model, } \\
\text { pendekatan, } \\
\text { metode, } \\
\begin{array}{l}\text { pembelajaran } \\
\text { peknis }\end{array}\end{array}$ & $\begin{array}{l}\text { dan keterampilan anak } \\
\text { berupa materi tes, video- } \\
\text { video tutorial, pelatihan, } \\
\text { dan seminar online. }\end{array}$ & $\begin{array}{l}\text { Pelatihan dan } \\
\text { pengembangan kualitas } \\
\text { guru dalam mendidikan } \\
\text { anak berkebutuhan } \\
\text { khusus }\end{array}$ \\
\hline $\begin{array}{l}\text { Tentukan jadwal } \\
\text { bimbingan belajar } \\
\text { Bersama tutor }\end{array}$ & $\begin{array}{l}\text { Video panduan } \\
\text { mengajar anak } \\
\text { berkebutuhan khusus }\end{array}$ & \begin{tabular}{lr} 
Layanan & \multicolumn{2}{r}{ Konsultasi } \\
dengan para ahli \\
pendidikan
\end{tabular} & Layanan konsultasi \\
\hline $\begin{array}{l}\text { Tersedia video tutorial } \\
\text { pembelajaan yang bisa } \\
\text { diakses. }\end{array}$ & $\begin{array}{l}\text { Peningkatan kualitas } \\
\text { guru }\end{array}$ & $\begin{array}{l}\text { Memberikan penilaian, } \\
\text { kritik, saran, dan } \\
\text { masukan terhadap } \\
\text { layanan aplikasi }\end{array}$ & $\begin{array}{l}\text { Memberikan penilaian, } \\
\text { kritik, saran, dan } \\
\text { masukan terhadap } \\
\text { layanan aplikasi }\end{array}$ \\
\hline Tugas dan Project & Layanan reward tutor & $\begin{array}{c}\text { Mengikuti webinar } \\
\text { mengenai mendidik } \\
\text { anak berkebutuhan } \\
\text { khusus }\end{array}$ & $\begin{array}{l}\text { Menerima pelaporan } \\
\text { atas kondisi dan } \\
\text { perkembangan belajar } \\
\text { siswa }\end{array}$ \\
\hline $\begin{array}{l}\text { Pengenalan dan } \\
\text { Pengembangan Bakat } \\
\text { dan keterampilan }\end{array}$ & $\begin{array}{ll}\text { Layanan } & \text { konsultasi } \\
\text { dengan tutee }\end{array}$ & $\begin{array}{l}\text { Menerima pelaporan } \\
\text { atas kondisi dan } \\
\text { perkembangan belajar } \\
\text { anak }\end{array}$ & $\begin{array}{l}\text { Mengikuti webinar dan } \\
\text { pelatihan bagi para guru } \\
\text { untuk mendidik anak } \\
\text { berkebutuhan khusus }\end{array}$ \\
\hline Apresiasi pencapaian & $\begin{array}{l}\text { Layanan konsultasi } \\
\text { tutor dengan para ahli } \\
\text { pendidikan }\end{array}$ & - & - \\
\hline Konsultasi Online & $\begin{array}{l}\text { Memberikan penilaian, } \\
\text { kritik, saran, dan } \\
\text { masukan terhadap } \\
\text { layanan aplikasi }\end{array}$ & - & - \\
\hline $\begin{array}{l}\text { Memberikan penilaian, } \\
\text { kritik, saran, dan } \\
\text { masukan terhadap tutor } \\
\text { dan aplikasi }\end{array}$ & $\begin{array}{c}\text { Webinar dan pelatihan } \\
\text { kompetensi } \\
\text { membimbing anak } \\
\text { berkebutuhan khusus }\end{array}$ & - & - \\
\hline
\end{tabular}

Aplikasi EDUKEY dapat membantu tutor dan tutee yang merupakan siswa berkebutuhan khusus untuk mendapatkan pembelajaran yang sesuai dengan kebutuhannya, baik dalam segi kecepatan belajar, metode pengajaran pangajar, pembawaan pengajar, maupun materi pembelajaran. Aplikasi ini juga diharapkan dapat menunjang pemahaman siswa ketika mereka berada di dalam kelas di sekolah formal. Selain itu, peneliti mengharapkan aplikasi EDUKEY dapat menjaring pengajar-pengajar siswa berkebutuhan khusus sehingga jumlah mereka semakin 
Jurnal Ilmiah KONTEKSTUAL, Volume. 3, No.01, Agustus 2021, pp. 33-41

banyak dan mau dengan sukacita mengajar siswa berkebutuhan khusus yang membutuhkan waktu tambahan untuk mempelajari suatu materi pembelajaran di sekolah.

Aplikasi EDUKEY mampu menjadi solusi atas kendala dan permasalahan dalam pembelajaran daring anak berkebutuhan khusus. Aplikasi ini dirancang dengan mengamati fenomena yang muncul terkait keadaaan pendidikan anak berekebutuhan khusus pada masa pembelajaran daring seperti penjelasan pada latar belakang di atas. Aplikasi tersebut diekspektasikan merupakan sebagai tambahan bimbingan bagi anak berkebutuhan khusus dalam belajar holisitik secara kognitif, afektif, dan psikomotor serta menolong dalam mempersiapkan untuk diri menghadapi kondisi kelas tatap muka di sekolah. Dengan adanya aplikasi ini, juga diharapkan dapat menolong para pendidik anak berkebutuhan khusus dalam mengatasi setiap permasalahan atau kendala yang terjadi.

Aplikasi EDUKEY memiliki keunikan dan keunggulan ditinjau dari pemakaian sistem aplikasi. Keunikannya aplikasi ini ada pada eksistensinya sebagai aplikasi bimbingan belajar yang diperuntukkan hanya untuk anak berkebutuhan khusus. Keunggulan yang dapat ditemukan dari aplikasi ini adalah sebagai berikut: a) pemakaian yang simple, mudah, dan disesuaikan dengan kondisi peserta didik berkebutuhan khusus, b) tersedianya para pendidik yang profesional dan memiliki pengalaman dalam mendidik anak berkebutuhan khusus melalui proses perekrutan dan seleksi, c) tersedianya fitur yang dapat diakes oleh siswa, pendidik, institusi sekolah, dan orang tua, dan d) akses aplikasi adalah gratis.

Pengoperasian aplikasi EDUKEY dapat dilakukan dengan mengakses teknologi aplikasi berbasis website dan mobile apps. Pengakesan aplikasi melalui website dilakukan sangat mudah dengan mengunjungi situs web pada mesin pencarian seperti google chrome atau mozilla. Situs website dibuat dengan menggunakan bahasa pemrograman dan didesain menggunakan sistem yang berkualitas bertujuan supaya mudah diakses oleh pengguna. Pada mobile apps, tampilan user interface aplikasi menarik dan tersedia fitur-fitur yang mudah digunakan. Terinsipirasi dari aplikasi bimbingan belajar Ruangguuru, aplikasi EDUKEY tersedia ikon menu dengan diberikan keterangan yang mudah dipahami serta letak menu, font, dan warna disesuaikan dengan kebutuhan pengguna. Aplikasi EDUKEY juga menyediakan fitur menu interaktif yang dapat dimanfaatkan oleh siswa, guru, orang tua, dan sekolah dalam mendapatkan dan menyampaikan informasi.

Pengguna siswa atau tutee dapat mengikuti kegiatan belajar melalui sesi sinkronus dan asinkronus. Sesi asinkronus adalah materi pembelajaran yang dapat diakses berupa teks dan video serta berdasarkan jenjang pendidikan baik SD, SMP, dan SMA. Materi teks berisi tentang bacaan, panduan, modul, jurnal, buku, dan artikel terkait dengan topik pelajaran yang dipelajari. Video pembelajaran yang tersedia adalah video tutorial yang disajikan oleh tutor. Sesi sinkronus adalah kelas tatap virtual tutor dengan tutee menggunakan aplikasi Zoom atau Microsoft. Pada sesi ini, tutor mengadakan interaksi virtual dengan tutee sesuai dengan jadwal yang disepakati bersama baik komunal ataupun individual.

Tutor merupakan pendidik yang berasal dari kalangan profesional dan memiliki pengalaman dalam mendidik anak berkebutuhan khusus. Para tutor dipilih berdasarkan sistem seleksi administrasi dan kemampuan yang ditetapkan oleh pengelolah aplikasi. Para pendidik di sekolah umum juga diberikan kesempatan untuk dapat bergabung menjadi tutor dengan diikutsertakan dalam pelatihan khusus sebagai pembekalan membimbing anak berkebutuhan khusus belajar dalam konteks pembelajaran daring. Para tutor akan membimbing belajar anak berkebutuhan khusus dengan memadukan pembelajaran yang bersifat holistik baik secara kognitif, afektif, dan psikomotor disesuaikan dengan karakteristik dan gaya belajar siswa.

Orang tua diberikan hak untuk mengakses aplikasi EDUKEY. Orang tua dapat menggunakan fitur-fitur yang tersedia untuk memantau perkembangan dan melihat hasil belajar anak. Tersedia juga layanan interaktif antara orang tua dengan tutor untuk berkomonikasi, sharing, dan pelaporan atas kondisi dan belajar anak. Selain itu, orang tua mendapatkan fasilitas berupa webinar online mengenai mendidik anak berkebutuhan khusus. Hal ini sangat baik karena orang tua akan mendapatkan pengetahuan dan keterampilan yang membantu mereka dalam mendidik anaknya dengan baik. 
Pengguna sekolah mendapatkan hak akses untuk memantau perkembangan belajar siswanya. Fitur khusus juga disediakan bagi sekolah untuk melihat hasil belajar siswa. Aplikasi akan melaporakan bagaimana kondisi belajar anak selama pembelajaran. Pihak Aplikasi dalam hal ini melalui tutor juga akan memberikan masukan positif kepada sekolah supaya siswa dapat belajar dan didik sebagaimana mestinya. Pihak sekolah dapat berkonsultasi dengan pihak aplikasi apabila ada hal-hal yang ingin dikonsultasikan mengenai kondisi dan belajar siswa.

Pengaktifan aplikasi EDUKEY terlebih dahulu diuji cobakan pada sekolah-sekolah yang memiliki hubungan mitra kerja dengan pihak aplikasi. Aplikasi ini disambut baik dan menjadi pioneer aplikasi bimbingan belajar pertama yang dikhususkan untuk anak berkebutuhan khusus. Mempertimbangkan situasi belajar daring anak berkebutuhan khusus yang mengalami kendala dan permasalahan, maka aplikasi dapat dipandang sebagai solusi dan membantu berbagai pihak dalam mendidik anak berkebutuhan khusus. Tentunya aplikasi ini akan berupaya secara profesional, sistematis, dan berkualitas demi membimbing anak berkebutuhan khusus dalam belajar. Setelah penerapan pada sekolah-sekolah mitra, maka aplikasi EDUKEY akan memperluas jangkauannya hingga berskala nasional untuk berdampak baik terhadap pendidikan bagi anak berkebutuhan khusus.

\section{Pembahasan}

Aplikasi EDUKEY membantu peserta didik melakukan kegiatan belajar mengajar secara daring karena merasa dimudahkan dengan fitur-fitur yang ada. Fitur-fitur yang disajikan sangat mudah untuk dipahami, sehingga tidak memunculkan beban baru bagi guru, siswa, atau orang tua dalam kegiatan pembelajaran daring. Hal ini berarti, aplikasi EDUKEY menjadi solusi pembelajaran daring bagi siswa berkebutuhan khusus.

Umpan balik yang diberikan pengguna terhadap aplikasi EDUKEY kebanyakan positif dan sesuai dengan tujuan peneliti membuat aplikasi ini. Keberhasilan penggunaan EDUKEY ini juga tentu didukung dengan pengajar yang sabar dan telaten serta extra time untuk mempelajari suatu materi adalah beberapa ciri anak slow learner [12]. Pengguna menyampaikan bahwa hal ini dapat diatasi dengan adanya EDUKEY karena siswa bertemu dengan pengajar yang memang mendedikasikan pengajaran kepada siswa-siswa yang memerlukan bantuannya secara ekstra untuk memahami materi.

Selain itu, beberapa pengguna juga menyampaikan bahwa aplikasi bimbingan belajar secara online ini membantu siswa untuk persiapan sebelum mengikuti pembelajaran di kelas dalam sekolah formal, tidak hanya siswa biasa, tetapi juga siswa berkebutuhan khusus yang memerlukan waktu tambahan untuk memahami pembelajaran di sekolah ataupun mendalami materi yang baru [13]. Satu dampak baik aplikasi EDUKEY terhadap pembelajaran siswa berkebutuhan khusus adalah testimoni pengguna yang merasa EDUKEY membuat siswa terbiasa dengan pola pembelajaran online sehingga mudah beradaptasi saat memasuki sesi pelajaran di sekolah, senada dengan beberapa penelitian lainnya mengenai aplikasi bimbingan belajar online lainnya [14].

Beberapa pengguna dari pihak sekolah menyampaikan bahwa aplikasi EDUKEY juga membantu sekolah menemukan pengajar-pengajar siswa berkebutuhan khusus yang dapat membantu mereka mengajar di sekolah maupun lewat aplikasi. Jumlah guru di beberapa SLB maupun sekolah inklusif di Indonesia belum cukup untuk meng-handle semua anak secara bersamaan. Maka dari itu, dengan tenaga pengajar yang ada di aplikasi EDUKEY, setidaknya sekolah tahu bahwa ada pengajar-pengajar di luar sana yang turut membantu siswa-siswi mereka belajar dengan baik [15].

\section{SIMPULAN}

Aplikasi EDUKEY dapat bermanfaat untuk digunakan sarana bimbingan belajar daring bagi anak berkebutuhan khusus terutama anak-anak slow learner, tunalaras, dan kesulitan belajar yang menjalani pendidikan di sekolah-sekolah SLB ataupun inklusi. Manfaat aplikasi dapat dirasakan anak berkebutuhan khusus melalui tutor yang profesional dan berpengalaman 
dibidangnya, metode pembelajaran bervariasi, dan tersedianya berbagai fitur yang menunjang aktivitas belajar dan perkembangan kognitif, afektif, dan psikomotor siswa. Selain itu, aplikasi juga dapat digunakan oleh orang tua dan pihak sekolah dalam keberlangsungan proses belajar anak berkebutuhan khusus. Berdasarkan peneltian yang dilakukan, pengguna menyampaikan sangat terbantu dalam belajar dan mengajar dengan adanya aplikasi EDUKEY. Berdasarkan hal itu, aplikasi EDUKEY dinilai dan dirasakan dampak yang baik dalam pendidikan anak berkebutuhan khusus dalam konteks pembelajaran daring.

\section{DAFTAR PUSTAKA}

[1] M. R. Yerusalem, A. F. Rochim, and K. T. Martono, "Desain dan implementasi sistem pembelajaran jarak jauh di program studi sistem komputer," Jurnal Teknologi dan Sistem Komputer, vol. 3, no. 4, p. 481, 2015, [Online]. Available: https://jtsiskom.undip.ac.id/index.php/jtsiskom/article/view/12668.

[2] K. Hernawati, "E-learning untuk siswa berkebutuhan khusus," Matematika dan Pendidikan Karakter dalam Pembelajaran. FMIPA UNY, pp. 138-149, 2011.

[3] N. Khabibah, "Penanganan instruksional bagi anak lambat belajar (slow learner)," Didaktita, vol. 19, no. 2, pp. 26-32, 2013.

[4] A. Setiawan, "Mengembangkan motivasi belajar pada anak tunalaras," Jassi, vol. 8, no. 1, pp. 54-60, 2009.

[5] I. Handayani, Q. Aini, and Y. Oktavyanti, "Penggunaan RinfoCal sebagai aplikasi pengingat (reminder) kegiatan akademik pada perguruan tinggi," CCIT Journal, vol. 9, no. 1, pp. 13-26, 2015.

[6] R. M. Erawati, I. L.; Sudjarwo; Sinaga, "Pendidikan karakter bangsa pada anak berkebutuhan khusus dalam pendidikan inklusif," Jurnal Studi Sosial, vol. 4, no. 1, pp. 20-29, 2016.

[7] A. D. Anjarsari, "Penyelenggaraan pendidikan inklusi pada jenjang SD, SMP, dan SMA di Kabupaten Sidoarjo," JPI (Jurnal Pendidikan Inklusi), vol. 1, no. 2, pp. 91-104, 2015, doi: 10.26740/inklusi.v1n2.p91-104.

[8] F. Fembriani, T. R. Koroh, P. Pasmiyati, and R. Polin, "Efektifitas edmodo terhadap hasil Belajar mahasiswa PGSD Universitas Nusa Cendana," Jurnal Ilmiah KONTEKSTUAL, vol. 2, no. 1, pp. 8-14, 2020, [Online]. Available: http://jurnal.umus.ac.id/index.php/kontekstual/article/view/243.

[9] K. A. Akhmad, "Pemanfaatan media sosial bagi pengembangan pemasaran UMKM (Studi deskriptif kualitatif pada distro di Kota Surakarta)," DutaCom Journal, vol. 9, no. 1, pp. 43-54, 2015.

[10] S. Alter, "Sociotechnical systems through a work system lens: A possible path for reconciling system conceptualizations, business realities, and humanist values in IS Development," CEUR Workshop Proceedings, vol. 1374, pp. 32-39, 2015.

[11] T. Sagirani, N. Wahyuningtyas, S. H. E. Wulandari, and W. W. Efendi, "Prototipe aplikasi pembelajaran bagi anak berkebutuhan khusus dengan menerapkan pendekatan gamification," Jurnal Teknik, vol. 18, no. 2, pp. 101-111, 2020, [Online]. Available: https://jt.ft.ung.ac.id/index.php/jt/article/view/77.

[12] L. Maftuhatin, "Evaluasi pembelajaran anak berkebutuhan khusus (ABK) di kelas inklusif di SD Plus Darul 'Ulum Jombang," Religi: Jurnal Studi Islam, vol. 5, no. 2, pp. 201-227, 2014.

[13] S. Gideon, "Peran media bimbingan belajar online Ruangguru dalam pembelajaran IPA bagi siswa SMP dan SMA masa kini: Sebuah pengantar," Jurnal Dinamika Pendidikan, vol. 11, no. 2, p. 167, Aug. 2018, [Online]. Available: http://ejournal.uki.ac.id/index.php/jdp/article/view/813.

[14] A. Ramadhayanti, "Analisis strategi belajar dengan metode bimbel online terhadap kemampuan pemahaman kosa kata bahasa Inggris dan pronunciation (pengucapan/pelafalan) berbahasa remaja saat ini," KREDO : Jurnal Ilmiah Bahasa dan 
Sastra, vol. 2, no. 1, pp. 39-52, 2018, [Online]. Available: https://jurnal.umk.ac.id/index.php/kredo/article/view/2580.

[15] P. Kepri, "Pemerintah terus dukung perkembangan SLB," ProPinang, 2020. 